\title{
PERTUMBUHAN EKONOMI PROVINSI SUMATERA SELATAN TAHUN 2008-2017
}

\author{
Saddam Husen \\ Fakultas Ekonomi dan Bisnis Islam UIN Raden Fatah Palembang \\ adamsahilindra@gmail.com \\ Yudi Armansyah \\ Fakultas Syariah UIN STS Jambi \\ yudiarmansyah@uinjambi.ac.id
}

\begin{abstract}
ABSTRAK
Penelitian ini bertujuan untuk menganalisis pengaruh angkatan kerja, investasi, realisasi PMA, realisasi PMDN dan belanja pemerintah daerah terhadap Pertumbuhan Ekonomi Provinsi Sumatera Selatan selama kurun waktu 2008-2017. Penelitian ini menggunakan data runtut waktu tahun 2008-2017 dan menggunakan analisa regresi data time series dengan bantuan perangkat lunak Eviews 10.0. Temuan dari penelitian ini menunjukkan bahwa investasi (PMA dan PMDN) tidak berpengaruh signifikan terhadap pertumbuhan ekonomi Provinsi Sumatera Selatan, sedangkan Tenaga Kerja dan belanja pemerintah daerah secara keseluruhan memberi dampak positif terhadap Pertumbuhan Ekonomi Provinsi Sumatera Selatan. Sebagai upaya meningkatkan Pertumbuhan Ekonomi Provinsi Sumatera Selatan, maka diperlukan kebijakan yang mendorong minat berinvestasi di daerah dan pemerataan investasi khususnya wilayah-wilayah di kabupaten. Pengembangan usaha sebaiknya diarahkan pada kegiatan yang bersifat padat karya agar mampu menyerap tenaga kerja sebanyak mungkin. Pada akhirnya peran pemerintah daerah melalui pengeluaran pemerintah yang dapat merangsang peningkatan variabel investasi dan penyerapan angkatan kerja diharapkan mampu meningkatkan kegiatan ekonomi daerah guna tercapainya pertumbuhan ekonomi dan peningkatan pendapatan perkapita masyarakat.

Kata Kunci : Pertumbuban Ekonomi, Sumatera Selatan : Investasi, Tenaga Kerja, Pengeluaran Pemerintah Daerah.
\end{abstract}

\section{ABSTRACT}

This study aims to analyze the influence of the labor force, investment, FDI realization, PMDN realization and local government spending on the Economic Growth of South Sumatra Province during the period 2008-2017. This study uses time series data for 2008-2017 and uses time series data regression analysis with the help of Eviews 10.0 software. The findings of this study indicate that investment (PMA and PMDN) has no significant effect on the economic growth of the South Sumatra Province, while the Labor and regional government spending as a whole has a positive impact on the Economic Growth of the South Sumatra Province. As an effort to increase the Economic Growth of the Province of South Sumatra, policies are needed that encourage investment in the regions and equitable investment, especially in the districts. Business development should be directed at activities that are labor-intensive in order to be able to absorb as many workers as possible. In the end, the role of regional governments through government spending that can stimulate an increase in investment variables and absorption of the workforce is expected to be able to increase regional economic activity in order to achieve economic growth and increase income per capita.

Keywords: Economic Growth, South Sumatra: Investment, Labor, Regional Government Spending.

Iltizam Journal Of Shariah Economic Research, Vol. 4, No. 1, 2020

Fakultas Ekonomi dan Bisnis Islam UIN Sulthan Thaha Saifuddin Jambi

E-ISSN: 2598-2540, P-ISSN: 2598-2222 


\section{PENDAHULUAN}

Pertumbuhan ekonomi suatu negara merupakan progres keberhasilan pemerintah dalam meningkatkan taraf hidup masyarakat, yaitu pertumbuhan ekonomi ialah proses kenaikan output perkapita yang terus menerus dalam jangka panjang. Pertumbuhan ekonomi tersebut merupakan salah satu indikator keberhasilan pembangunan. Seperti yang diungkapkan Sukirno, pembangunan ekonomi merupakan tahap berupa dalam meningkatkan penghasilan atau pendapatan perkapita negara dengan cara mengolah sumbersumber ekonomi menjadi output riil ${ }^{1}$. Hal ini dilakukan melalui lima tahap penting, yaitu penanaman modal, pemanfaatan teknologi, peningkatan pengetahuan, dan pengelolaan keterampilan, serta penambahan kemampuan berorganisasi. Dengan menggunakan kelima tahap tersebut, maka pembangunan ekonomi dapat berjalan dan tumbuh dengan baik.

Perbangunan ekonomi adalah masalah yang penting dalam perekonomian suatu negara yang sudah menjadi agenda setiap tahunnya. Pembangunan ekonomi yang dilakukan oleh suatu negara bertujuan untuk mewujudkan masyarakat yang sejahtera, makmur dan adil. Pembangunan ekonomi adalah suatu proses yang menyebabkan kenaikan pendapatan riil per kapita penduduk suatu negara dalam jangka panjang yang disertai oleh perbaikan sistem kelembagaan. $^{2}$

Secara struktur pemerintah daerahpun ikut berperan penting terhadap pembangunan ekonomi nasional secara keseluruhan. Masing-masing Provinsi di Indonesia termasuk Provinsi Sumatera Selatan harus mampu menghadapi tantangan perekonomian global yaitu mencapai pertumbuhan ekonomi yang tinggi serta mampu mengatasi permasalahan pembangunan yang terjadi terutama dalam era reformasi dimana masing-masing daerah memiliki kebebasan seluas-luasnya untuk mengelola kekayaan daerah yang dimiliki dan

${ }^{1}$ Sadono Sukirno , Makroekonomi Modern, (Jakarta: PT. Raja Grafindo,2004), hlm. 33 
memanfaatkannya untuk kegiatan pembangunan di daerah tersebut.

Dalam analisis makro, tingkat pertumbuhan ekonomi yang dicapai oleh suatu daerah diukur dari perkembangan pendapatan riil yang dicapai suatu daerah. Teori Pertumbuhan Ekonomi Neo Klasik menyatakan pertumbuhan ekonomi (di daerah diukur dengan pertumbuhan PDRB) bergantung pada perkembangan faktor-faktor produksi yaitu ; modal, tenaga kerja dan teknologi) ${ }^{3}$.

Pembangunan di Provinsi Sumatera Selatan yang berlangsung secara menyeluruh dan berkesinambungan telah meningkatkan perekonomian masyarakat. Pencapaian hasil-hasil pembangunan yang sangat dirasakan masyarakat merupakan agregat pembangunan dari 17 Kabupaten/Kota di Sumatera Selatan yang tidak terlepas dari usaha keras bersama-sama antara pemerintah dan masyarakat. namun di sisi lain berbagai kendala dalam memaksimalkan potensi sumber daya manusia dan sumber modal masih dihadapi oleh penentu kebijakan di tingkat Provinsi maupun di Kabupaten/Kota.

Kendala yang di hadapi adalah, daya saing sumber daya manusia (SDM) Indonesia masih tertinggal jika di bandingkan dengan negara asean lainnya, kedua, lebih dari separuh pekerja Indonesia masih berada disektor informal dengan produktivitas yang rendah, ketiga, masih rendahnya akses kelompok rentan seperti perempuan, penyandang disabilitas, serta penduduk daerah tertinggal terhadap kesempatan kerja yang berkualitas. Begitupun dengan Kendala dalam memaksimalkan sumber modal dikarenakan ketiadaan kepastian hukum yang membuat penanam modal ragu dalam berinvestasi, beban pajak yang besar, kualitas SDM yang relatif rendah, masalah sertifikasi izin bangunan dan zonasi lahan, birokrasi yang tidak efesien, peraturan pusat dan daerah yg tidak sinkron dan yang terakhir masalah infrastruktur yang tidak mendukung. 
Nilai pertumbuhan dari pembangunan yang terjadi di Provinsi Sumatera Selatan secara fisik berkembang sangat signifikan di banding tahun-tahun sebelumnya. Kenyataan ini terlihat dari lengkapnya berbagai fasilitas olahraga yang dibangun di Sport Centre Jakabaring, banyaknya hotel berbagai kelas yang didirikan, perbaikan, pelebaran dan pembuatan jalan-jalan di Kota Palembang. Tetapi apakah pembangunan tersebut berdampak terhadap perbaikan kesejahteraan masyarakat Sumatera Selatan, terutama untuk mengurai dan mengurangi kantong-kantong kemiskinan dan pengangguran di Sumatera Selatan.

Dari berbagai aspek diatas, tentu masalah investasi, tenaga kerja dan pengeluaran pemerintah akan menjadi dominan, hal itu disebabkan output riil dari pada kegiatan-kegiatan dan nilai investasi di Provinsi Sumatera Selatan, dan selanjutnya menjadi latar belakang penulis untuk melakukan penelitian.

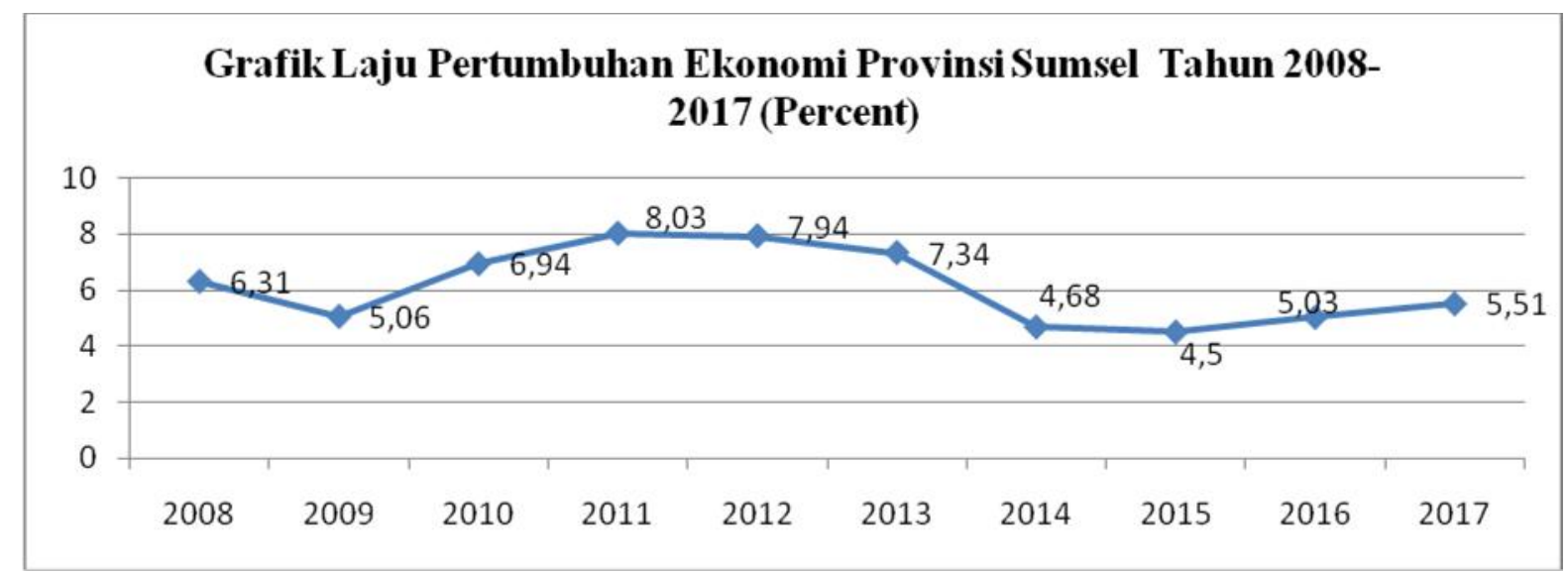

Sumber : BPS Prov. Sumatera Selatan (data diolah)

Seperti terlihat pada gambar 1.1 dapat diketahui bahwa selama kurun waktu 2008-2017 Provinsi Sumatera Selatan mengalami pertumbuhan rata-rata $5,48 \%$ di atas pertumbuhan ekonomi nasional (rata-rata 5,1\%). Pertumbuhan ekonomi yang tertinggi terjadi pada tahun 2011 yaitu sebesar 8,03\%, 
sedangkan pertumbuhan ekonomi yang terendah terjadi pada tahun 2015 yaitu sebesar $4,50 \%$.

Dalam teori ekonomi makro dari sisi pertumbuhan ekonomi regional Provinsi Sumtera Selatan 2008-2017 relatif stagnan, hal ini disebabkan tingkat produktivitas masih rendah. Badan Perencanaan Pembangunan Nasional (Bappenas) melalui staf ahli Menteri Perencanaan Pembangunan Nasional, Bambang Priyambodo menjelaskan penyebab stagnannya pertumbuhan ekonomi adalah masalah produktivitas. Dia menjelaskan tingkat produktivitas Indonesia pada umumnya masih tertinggal dari negara lain, misalnya transformasi struktural yang tercermin dari tenaga kerja Indonesia. Menurutnya lebih dari 30\% tenaga kerja bekerja di sektor pertanian. Selain itu juga masalah deindustrialisasi. ${ }^{4}$

\section{Realisasi Investasi Provinsi Sumatera Selatan Tahun 2008-2017(Triliun)}

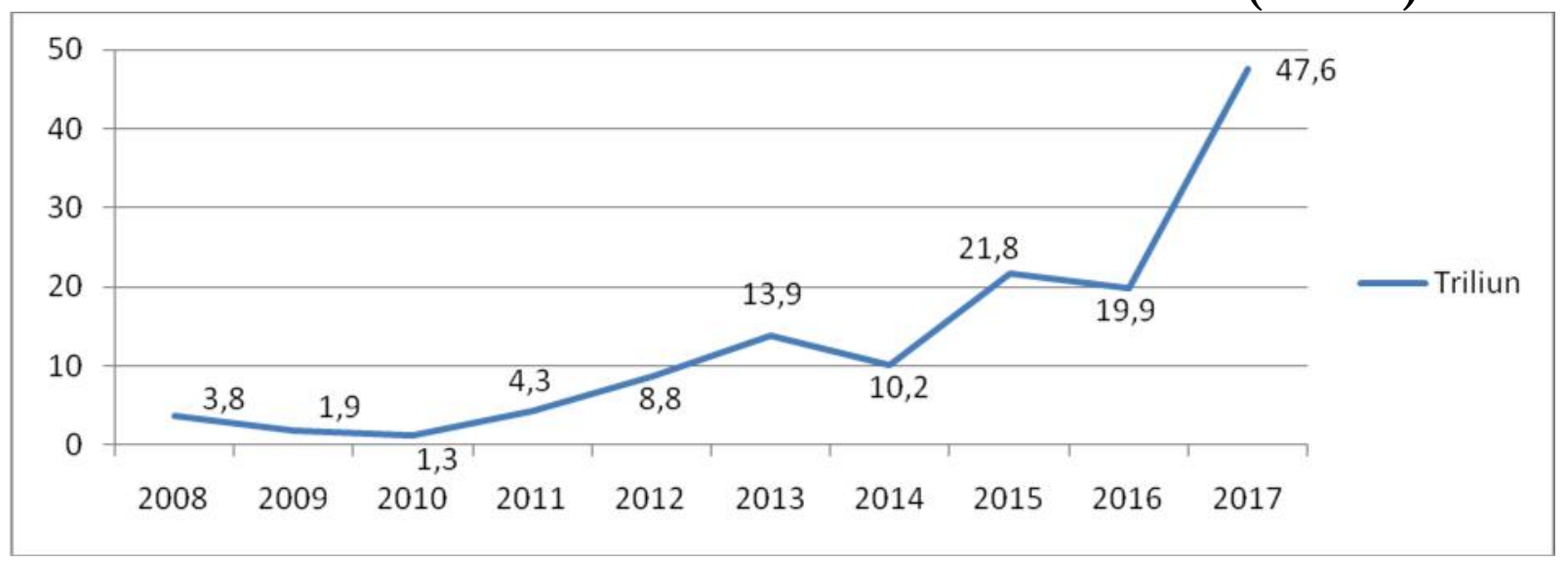

Sumber : DPM-PTSP Prov. Sumsel (data diolah)

Dari grafik di atas dapat dilihat bahwa Pertumbuhan Investasi (PMDN dan PMA) Sumatera Selatan mengalami fluktuatif, investasi tertinggi sebesar 95,6\% berada ditahun 2014 sedangkan pertumbuhan melambat diangka 71,1\% pada tahun sesudahnya. Selama sepuluh tahun terakhir rata-rata tumbuh 54.14\% dengan jumlah proyek sebanyak 682. Dengan demikian diharapkan 
bahwa proyek dan investasi tersebut dapat memberdayakan potensi ekonomi di masyarakat yang lebih tinggi.

\section{Tingkat Belum Bekerja Provinsi Sumatera Selatan Tahun 2008-2017}

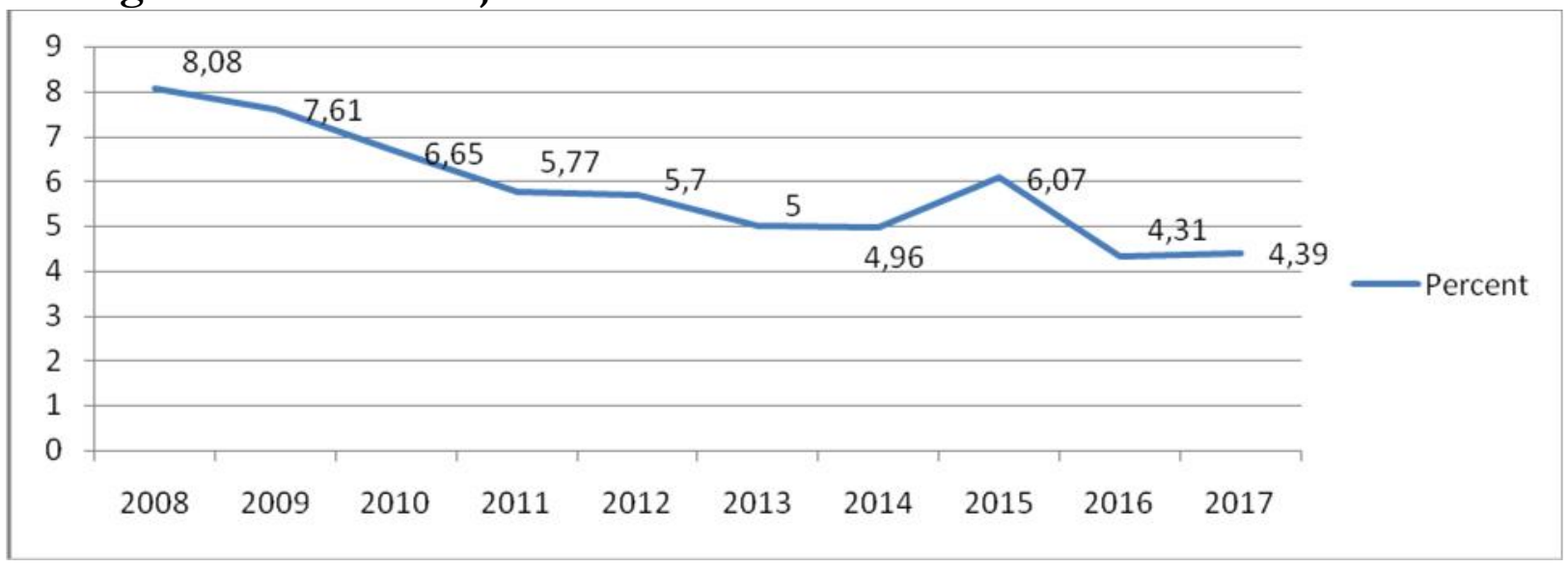

Sumber : BPS Prov. Sumatera Selatan (data diolah)

Dari grafik di atas terlihat bahwa tingkat pengangguran di Provinsi Sumatera Selatan masih mengalami naik turun, pertumbuhan setiap tahun dengan rata rata 5,9\% ini menunjukan bahwa penduduk Sumatera Selatan masih banyak yang pengangguran dan belum terserap kerja. Hingga tahun 2017 hanya sebesar 3.942.534 (52,7\%) yang sudah bekerja dari total penduduk Provinsi Sumatera Selatan sebesar 7.481.604 orang. Kenaikan pengangguran yang cukup signifikan berada di tahun 2008 sebesar 8,08 \% menurun terendah di tahun 2013 sebesar 5\% dan naik kembali dengan angka yg cukup tinggi sebesar 6,07 \% di tahun 2015. Artinya penyerapan tenaga kerja di Sumatera Selatan belum maksimal dibandingkan Jumlah penduduk bekerja kenaikannya tidak signifikan, sementara jumlah pencari kerja peningkatannya sangat lambat 5,9\%. Hal ini mengindikasikan bahwa kebijakan-kebijakan pembangunan manusia di Provinsi Sumatera Selatan belum sepenuhnya mengakomodasi kepentingan percepatan ekonomi lokal. 


\section{Realisasi Pengeluaran Pemerintah Daerah Provinsi Sumatera Selatan Tahun 2008-2017}

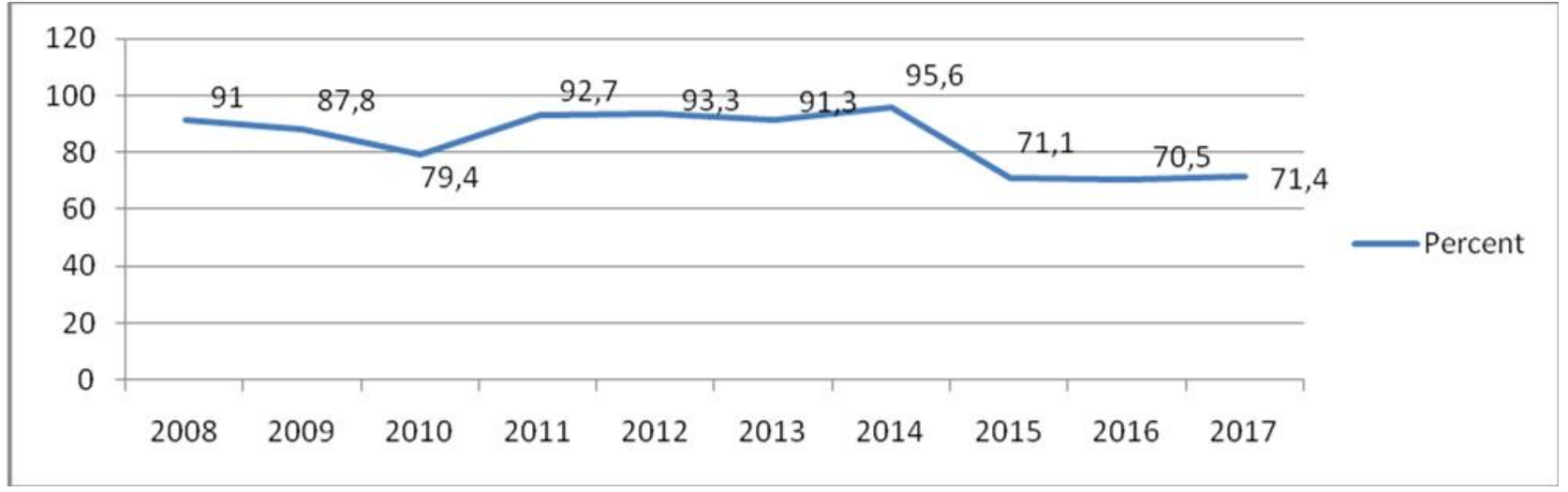

Sumber : Sumber : BPS Prov. Sumsel (data diolah)

Selama tahun 2008-2017 Pemerintah Daerah Provinsi Sumatera Selatan telah meningkatkan belanja daerahnya rata-rata sebesar $79 \%$ tiap tahunnya. Belanja daerah tersebut terdiri dari belanja aparatur daerah dan belanja pelayanan publik kemudian di akumulasi menjadi anggaran yang telah terealisasi. Anggaran yg sudah terserap dalam pengeluaran pemerintah daerah naik rata-rata sebesar $84,42 \%$, Ini diharapkan dapat mengoptimalkan pembangunan ekonomi di Provinsi Sumatera Selatan.

PDRB sebagai tolok ukur pertumbuhan suatu ekonomi regional juga tidak bisa lepas dari peran pengeluaran pemerintah di sektor layanan publik. Pengeluaran pemerintah daerah diukur dari total belanja rutin dan belanja pembangunan yang dialokasikan dalam anggaran daerah. Semakin besar pengeluaran pemerintah daerah yang produktif maka semakin memperbesar tingkat perekonomian suatu daerah ${ }^{5}$

Pengeluaran / konsumsi pemerintah yang terlalu kecil akan merugikan pertumbuhan ekonomi. Pengeluaran pemerintah yang proporsional akan meningkatkan pertumbuhan ekonomi. Pada umumnya pengeluaran pemerintah membawa dampak positif bagi pertumbuhan ekonomi.

${ }^{5}$ Wibisono.Sumber-Sumber Pertumbuhan Ekonomi Regional: Studi Empiris antar Provinsi di Indonesia,1994-2008. (Jakarta: FEUI. 2004) hlm. 51 


\section{METODE PENELITIAN}

Data yang digunakan dalam penelitian adalah data sekunder yang mempunyai sifat runtut waktu (time series) periode 2008-2017. Penelitian ini menggunakan data yang bersumber dari BPS (Badan Pusat Statistik) Provinsi Sumatera Selatan. Populasi dalam penelitian ini adalah seluruh Provinsi Sumatera Selatan. Periode penelitian ini adalah dari tahun 2008 -2017.

Untuk itu sampel yang diambil harus representatif. Teknik sampling yang digunakan dalam penelitian ini adalah Sampling Jenuh. Sampling Jenuh adalah teknik penentuan sampel bila semua anggota populasi digunakan sebagai sampel ${ }^{6}$. Hal ini sering dilakukan bila jumlah populasi relatif kecil, kurang dari 30 orang. Istilah lain sampel jenuh adalah sensus, dimana semua anggota populasi dijadikan sampel. Kriteria syarat yang digunakan sebagai dasar pengambilan sampel adalah data dari keseluruhan variabel dengan jangka tahun 2008 - 2017. Berdasarkan kriteria untuk menentukan sampel tersebut, maka sampel yang digunakan dalam penelitian ini adalah data akumulasi 17 kabupaten kota di Provinsi Sumatera Selatan pada tahun 2008-2017.

Untuk mengetahui pengaruh Investasi Swasta, Tenaga Kerja dan Pengeluaran Pemerintah terhadap Pertumbuhan Ekonomi di Provinsi Sumatera Selatan digunakan analisis kuantitatif yaitu dengan menggunakan regresi linier berganda atau teknik metode kuadrat terkecil biasa (Ordinary Least Square) dengan menggunakan eviews 10.

Penelitian ini menggunakan analisis dengan model permintaan berikut:

$Y=F(I, T K, G)$

Kemudian model dibentuk menjadi model regresi sebagai berikut :

$$
\mathrm{Y}=\beta_{0}+\beta_{1} \mathrm{I}+\beta_{2} \mathrm{TK}+\beta_{3} \mathrm{G}+e_{t}
$$

Dimana :

$\mathrm{Y}$

$=$ Pertumbuhan Ekonomi Provinsi Sumatera Selatan dari Tahun 2008 sampai 2017 (juta)

\footnotetext{
${ }^{6}$ Sugiyono.Metode Penelitian Kuantitatif Kualitatif dan $R \&$ D. hlm. 61
} 


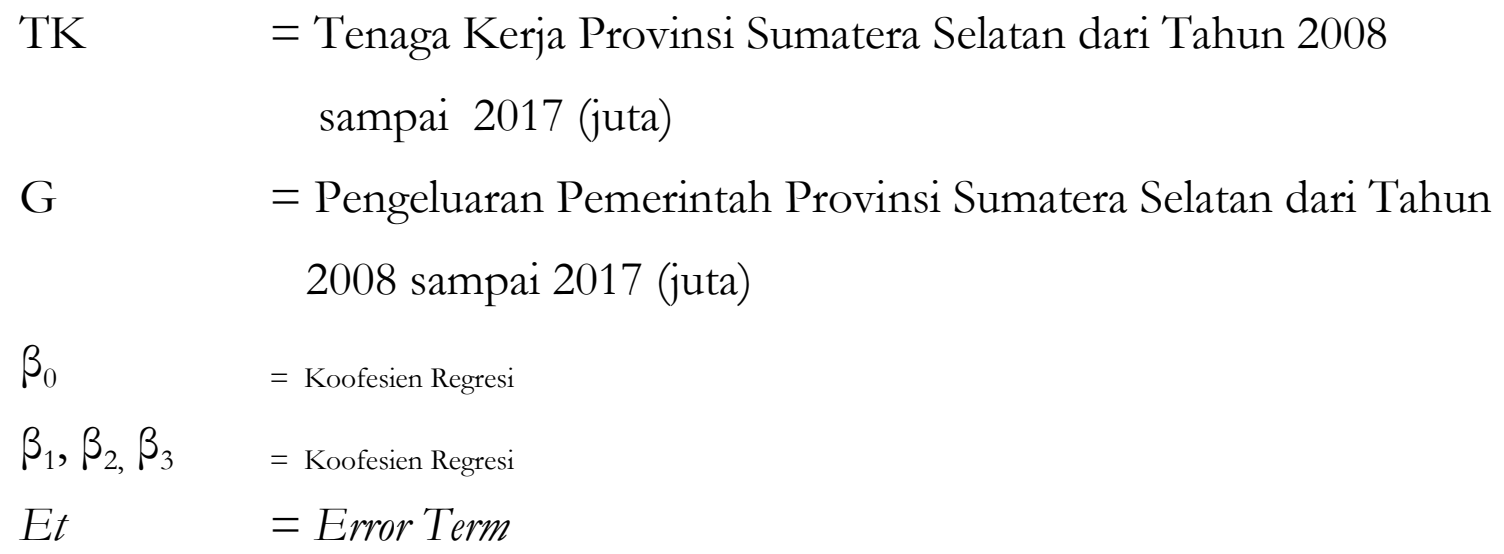

\section{HASIL PENELITIAN DAN PEMBAHASAN}

Pertumbuhan PDRB Sumatera Selatan Tahun 2008-2017

\begin{tabular}{|c|c|c|}
\hline Tahun & Angka (Miliar) & Percent \\
\hline 2008 & 58.065 .455 & 6,31 \\
\hline 2009 & 60.452 .944 & 5,06 \\
\hline 2010 & 63.859 .140 & 6,94 \\
\hline 2011 & 68.008 .496 & 8,03 \\
\hline 2012 & 72.095 .883 & 7,94 \\
\hline 2013 & 76.409 .763 & 7,34 \\
\hline 2014 & 243.297 .771 & 4,68 \\
\hline 2015 & 254.044 .875 & 4,5 \\
\hline 2016 & 266.853 .737 & 5,03 \\
\hline 2017 & 281.544 .365 & 5,51 \\
\hline
\end{tabular}

Sumber : BPS Prov. Sumatera Selatan (data diolah)

Kinerja perekonomian Indonesia pada tahun 2008 cukup menggembirakan di tengah perekonomian Indonesia yang melemah. Pertumbuhan ekonomi dapat dipertahankan pada tingkat yang cukup tinggi, yaitu 6,31\%. Di tengah menurunnya kinerja ekspor, pertumbuhan ekonomi lebih banyak ditopang oleh permintaan domestik yang tetap kuat, menyebabkan terjadinya ketidakseimbangan neraca transaksi berjalan. Secara keseluruhan, penyesuaian ekonomi tahun 2008 tetap terkendali, di mana perlambatan ekonomi 2009 tidak terlalu dalam yakni 5,06\%. Perekonomian Sumatera Selatan tahun 2010 tumbuh cukup signifikan sebesar 6,94\%, naik 
cukup baik dibandingkan dengan 5,06\% pada tahun 2009. Dari sisi eksternal, dinamika tersebut terutama dipengaruhi oleh pertumbuhan investasi dan ditopang oleh konsumsi rumah tangga dan didorong oleh aktivitas perekonomian di kota Palembang 5,59\% dan Kabupaten OKI 4,66\%. Dibandingkan dengan rata-rata pertumbuhan ekonomi kota/kabupaten lain relatif lebih tinggi.

Perekonomian Sumatera Selatan tahun 2011 mencatat perkembangan yang positif. Kinerja stabilitas makroekonomi semakin baik, pertumbuhan ekonomi semakin mengalami kenaikan dari 6,94\% pada 2010 menjadi 8,03\% di tahun 2011. dimana ini adalah kali pertama ekonomi Sumatera Selatan berada di atas 5 persen sejak 2008, ketika terjadi krisis keuangan global. Perekonomian Sumatera pada 2011 tetap berdaya tahan di tengah kondisi perekonomian global yang masih belum kuat. Namun pertumbuhan perekonomian Sumatera Selatan selama tahun 2012-2013 sedikit menurun dengan rata-rata sebesar 1,1 \%. Pada periode selanjutnya (2014-2017) pertumbuhan ekonomi relatif menurun signifikan dibandingkan pada periode tahun 2008-2013 dengan rata-rata 3,2\%, hal ini di sebabkan nilai insflasi ratarata sebesar 3,4\%. Selama tahun pengamatan pertumbuhan ekonomi Provinsi Sumatera Selatan rata-rata hanya tumbuh 0,24\% dengan pertumbuhan paling rendah pada tahun 2015 sebesar 4,3 \% sebagai akibat kenaikan komoditas harga barang makanan dan nilai inflasi tahun 2015 sebesar 3,10\%. 
Perkembangan Realisasi Penanaman Modal Dalam Negeri (PMDN) dan Penanaman Modal Asing (PMA) Provinsi Sumatera Selatan Tahun 2008-2017

\begin{tabular}{|c|c|c|c|c|}
\hline \multirow{2}{*}{ Tahun } & \multicolumn{2}{|c|}{ PMDN } & \multicolumn{2}{c|}{ PMA } \\
\cline { 2 - 5 } & $\begin{array}{c}\text { Jumlah } \\
\text { Proyek }\end{array}$ & $\begin{array}{c}\text { Realisasi (Miliar } \\
\text { Rp) }\end{array}$ & $\begin{array}{c}\text { Jumlah } \\
\text { Proyek }\end{array}$ & $\begin{array}{c}\text { Realisasi (Juta } \\
\text { USS) }\end{array}$ \\
\hline 2008 & 5 & 378.000 .000 .000 & 7 & 115.000 .000 \\
\hline 2009 & 4 & 580.000 .000 .000 & 4 & 57.000 .000 \\
\hline 2010 & 29 & 1.738 .000 .000 .000 & 51 & 186.000 .000 \\
\hline 2011 & 48 & 1.068 .000 .000 .000 & 99 & 557.000 .000 \\
\hline 2012 & 32 & 2.930 .000 .000 .000 & 107 & 786.000 .000 \\
\hline 2013 & 47 & 3.396 .000 .000 .000 & 142 & 486.000 .000 \\
\hline 2014 & 42 & 7.042 .000 .000 .000 & 114 & 1.057 .000 .000 \\
\hline 2015 & 77 & 10.944 .000 .000 .000 & 135 & 646.000 .000 \\
\hline 2016 & 165 & 8.534 .000 .000 .000 & 251 & 2.794 .000 .000 \\
\hline 2017 & 233 & 8.200 .000 .000 .000 & 261 & 1.183 .000 .000 \\
\hline Total & 682 & 44.810 .000 .000 .000 & 1171 & 7.867 .000 .000 \\
\hline
\end{tabular}

Sumber : Badan Penanaman Modal Prov. Sumsel (data diolah)

Selama kurun waktu tahun 2008-2017 di Provinsi Sumatera Selatan telah terealisasi sebanyak 1171 proyek dengan nilai sebesar $\$ 7.867 .000 .000$ (Rp.110.374.010.000.000) Sedangkan PMDN terealisasi sebesar Rp 44.810.000.000.000 dengan jumlah proyek 682.

Dari Tabel 1.2 dapat dilihat bahwa pertumbuhan realisasi PMDN mengalami fluktuatif dan selama sepuluh tahun terakhir rata-rata tumbuh $54.14 \%$ dengan jumlah proyek sebanyak 682. sedangkan jumlah proyek PMA dari tahun ke tahun meningkat tetapi pertumbuhannya rata-rata (139.76 \%). Hal ini menunjukkan bahwa Pemerintah Provinsi Sumatera Selatan sudah optimal dalam usaha menarik investor asing yang dapat memberdayakan potensi ekonomi di wilayahnya. 


\section{Kondisi Ketenagakerjaan Sumatera Selatan}

Angkatan Keja Provinsi Sumatera Selatan Tahun 2008-2017

\begin{tabular}{|c|c|c|c|c|}
\hline \multirow[b]{2}{*}{ Tahun } & \multicolumn{2}{|c|}{ Angkatan Kerja } & \multirow[b]{2}{*}{ Sub Jumlah } & \multirow{2}{*}{$\begin{array}{c}\text { Tingkat } \\
\text { Pengangguran } \\
(\%)\end{array}$} \\
\hline & Bekerja & $\begin{array}{c}\text { Pencari } \\
\text { Kerja }\end{array}$ & & \\
\hline 2008 & 3.191 .355 & 280657 & 3.472 .012 & 8,08 \\
\hline 2009 & 3.196 .894 & 263471 & 3.460 .365 & 7,61 \\
\hline 2010 & 3.421 .193 & 243851 & 3.665 .044 & 6,65 \\
\hline 2011 & 3.553 .104 & 217569 & 3.770 .637 & 5,77 \\
\hline 2012 & 3.532 .932 & 213441 & 3.746 .373 & 5,70 \\
\hline 2013 & 3.464 .620 & 182376 & 3.646 .996 & 5,00 \\
\hline 2014 & 3.692 .806 & 192868 & 3.885 .674 & 4,96 \\
\hline 2015 & 3.695 .866 & 238921 & 3.934 .787 & 6,07 \\
\hline 2016 & 3.998 .637 & 180157 & 4.178 .794 & 4,31 \\
\hline 2017 & 3.942 .534 & 181135 & 4.123 .669 & 4,39 \\
\hline
\end{tabular}

Sumber : BPS Prov. Sumatera Selatan (data diolah)

Dari Tabel di atas terlihat bahwa sebagian tingkat pengangguran di Provinsi Sumatera Selatan mengalami penurunan setiap tahun dengan rata rata 5,9 \% ini menunjukan bahwa penduduk Sumatera Selatan masih banyak yang pengangguran dan belum terserap kerja. Hingga tahun 2017 hanya sebesar 3.942.534 (52,7\%) yang sudah bekerja dari total penduduk Provinsi Sumatera Selatan sebesar 7.481.604 orang. Jumlah penduduk bekerja kenaikannya tidak signifikan, sementara jumlah pencari kerja peningkatannya sangat lambat 5,9\%. Hal ini mengindikasikan bahwa kebijakan-kebijakan pembangunan manusia di Provinsi Sumatera Selatan belum sepenuhnya mengakomodasi kepentingan percepatan ekonomi lokal. 


\section{Realisasi Pengeluaran Pemerintah Daerah Provinsi Sumatera Selatan Tahun 2008-2017}

\begin{tabular}{|c|c|c|r|}
\hline \multirow{2}{*}{ Tahun } & \multirow{2}{*}{ Anggaran } & \multicolumn{2}{|c|}{ Realisasi } \\
\cline { 3 - 4 } & & Angka & \multicolumn{1}{|c|}{ Percent } \\
\hline 2008 & $2.557 .656 .136 .722,00$ & $2.328 .231 .676 .101,00$ & 91 \\
\hline 2009 & $2.718 .470 .708 .751,00$ & $2.386 .788 .511 .614,32$ & 87,8 \\
\hline 2010 & 2.947 .481 .801 .876 .62 & $2.341 .327 .091 .455,29$ & 79,4 \\
\hline 2011 & $4.106 .682 .479 .981,83$ & $3.806 .079 .835 .012,47$ & 92,7 \\
\hline 2012 & $4.886 .553 .394 .359,91$ & $4.561 .372 .722 .681,00$ & 93,3 \\
\hline 2013 & $6.221 .526 .149 .006,89$ & $5.678 .703 .610 .531,20$ & 91,3 \\
\hline 2014 & $6.048 .607 .430 .664,52$ & $5.781 .570 .143 .910,34$ & 95,6 \\
\hline 2015 & $7.273 .759 .375 .657,94$ & $5.169 .621 .852 .822,77$ & 71,1 \\
\hline 2016 & $7.033 .546 .476 .952,16$ & $4.962 .572 .330 .784,01$ & 70,6 \\
\hline 2017 & $8.976 .336 .397 .795,04$ & $6.409 .382 .404 .458,31$ & 71,4 \\
\hline
\end{tabular}

Sumber : BPKAD Prov. Sumatera Selatan (data diolah)

Selama tahun 2008-2017 Pemerintah Daerah Provinsi Sumatera Selatan telah meningkatkan belanja daerahnya rata-rata sebesar 14,21\% tiap tahunnya. Belanja daerah tersebut terdiri dari belanja aparatur daerah dan belanja pelayanan publik kemudian di akumulasi menjadi anggaran yang telah terealisasi. Anggaran yg sudah terserap dalam pengeluaran pemerintah daerah naik rata-rata sebesar $12.38 \%$, Ini diharapkan dapat mengoptimalkan pembangunan ekonomi di Provinsi Sumatera Selatan.

\section{Uji Asumsi Klasik}

\section{Uji Normalitas}

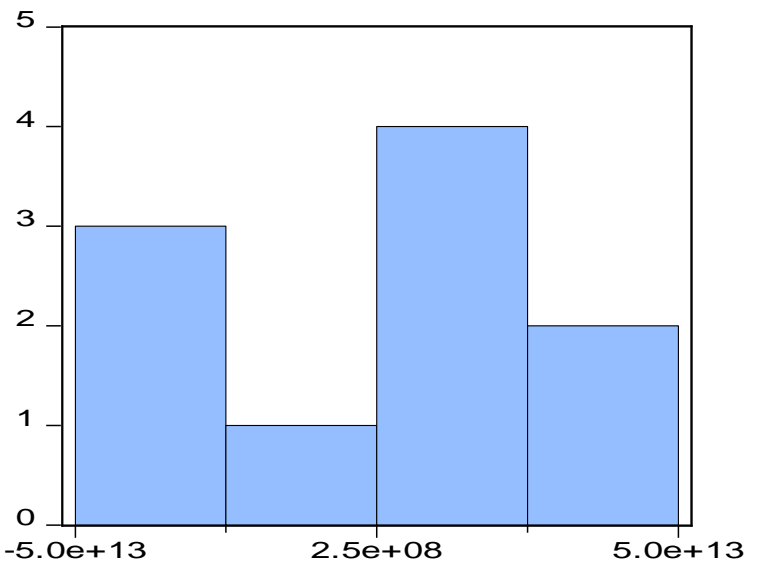

\begin{tabular}{lr}
\hline Series: Residuals \\
Sample 2008 2017 \\
Observations 10 \\
Mean & -0.039063 \\
Median & $3.00 e+12$ \\
Maximum & $4.04 e+13$ \\
Minimum & $-4.46 e+13$ \\
Std. Dev. & $2.79 e+13$ \\
Skewness & -0.242360 \\
Kurtosis & 1.909305 \\
& \\
Jarque-Bera & 0.593570 \\
Probability & 0.743204 \\
\hline
\end{tabular}

Uji normalitas menguji apakah dalam model regresi, variabel independen dan variabel dependen, keduanya terdistribusikan secara normal 
atau tidak, maka pengujian ini menggunakan bantuan komputer program Eviews 10.0. Normalitas data dalam penelitian dilihat dengan cara memperhatikan nilai Jarque-Bera lebih kecil dari chi-square tabel $0.593570<1.73961$, maka menunjukan data ini terdistribusi secara normal (memenuhi asumsi normalitas) atau bisa di lihat dari nilai Probabilitasnya lebih besar dari alpha 5\% 0.743204>0.05 maka dapat dikatakan data ini terbebas dari normalitas secara statistik.

Berdasarkan hasil pengolahan data maka didapatkan hasil bahwa semua data berdistribusi secara normal dan tidak terjadi penyimpangan, sehingga data yang dikumpulkan dapat diproses dengan metode-metode selanjutnya.

\section{a. Uji Multikolinieritas}

\section{Hasil Uji Multikolinearitas}

Variance Inflation Factors

Date: 04/14/20 Time: 00:01

Sample: 20082017

Included observations: 10

\begin{tabular}{cccc} 
Variable & $\begin{array}{c}\text { Coefficient } \\
\text { Variance }\end{array}$ & $\begin{array}{c}\text { Uncentered } \\
\text { VIF }\end{array}$ & $\begin{array}{c}\text { Centered } \\
\text { VIF }\end{array}$ \\
\hline \hline C & $1.63 \mathrm{E}+29$ & 1399.172 & NA \\
Investasi & 4.253381 & 15.17108 & 6.418852 \\
Angkatan Kerja & $1.68 \mathrm{E}+16$ & 1847.462 & 9.679845 \\
Pengeluaran Pemerintah & 151.7085 & 27.30473 & 2.785031 \\
\hline \hline
\end{tabular}

Dari perhitungan menggunakan program Eviews 10.0 dapat kita ketahui bahwa nilai VIF dan tolerance sebagai berikut :

1. Variabel Investasi mempunyai nilai VIF sebesar 6.418852 yang kurang dari nilai 10

2. Variabel Angkatan Kerja (AK) mempunyai nilai VIF sebesar 9.679845 yang kurang dari nilai 10

3. Variebel Pengeluaran Pemerintah (EXPD) mempunyai nilai VIF sebesar 2.785031 yang kurang dari nilai 10 
Dari ketentuan yang ada bahwa jika nilai VIF $<10$ maka tidak terjadi gejala multikolinearitas dan nilai-nilai yang didapat dari perhitungan adalah sesuai dengan ketetapan nilai VIF dan tolerance, dan dari hasil analisis diatas dapat diketahui nilai toleransi semua variabel independen (INV, AK, EXPD) nilai VIF kurang dari 10 maka dapat disimpulkan bahwa variabel independennya tidak terjadi multikolinieritas sehingga model tersebut telah memenuhi syarat asumsi klasik dalam analisis regresi 


\section{b. Uji Autokorelasi}

\section{Hasil Pengujian Durbin Watson}

Breusch-Godfrey Serial Correlation LM Test:

\begin{tabular}{llll}
\hline \hline F-statistic & 0.041340 & Prob. F $(2,4)$ & 0.9599 \\
Obs*R-squared & 0.202513 & Prob. Chi-Square(2) & 0.9037 \\
\hline \hline
\end{tabular}

Test Equation:

Dependent Variable: RESID

Method: Least Squares

Date: 04/14/20 Time: 00:19

Sample: 20082017

Included observations: 10

Presample missing value lagged residuals set to zero.

\begin{tabular}{lrlrr}
\hline \hline \multicolumn{1}{c}{ Variable } & Coefficient & Std. Error & t-Statistic & Prob. \\
\hline \hline C & $7.86 \mathrm{E}+13$ & $5.62 \mathrm{E}+14$ & 0.139671 & 0.8957 \\
X1 & 0.333850 & 2.764813 & 0.120750 & 0.9097 \\
X2 & -29142982 & $1.89 \mathrm{E}+08$ & -0.154576 & 0.8846 \\
X3 & 5.013847 & 24.74268 & 0.202640 & 0.8493 \\
\multicolumn{1}{c}{ RESID(-1) } & -0.106566 & 0.855340 & -0.124589 & 0.9069 \\
RESID(-2) & -0.260456 & 0.908658 & -0.286638 & 0.7886 \\
\hline \hline & & & & \\
R-squared & 0.020251 & Mean dependent var & -0.039063 \\
Adjusted R-squared & -1.204435 & S.D. dependent var & $2.79 \mathrm{E}+13$ \\
S.E. of regression & $4.14 \mathrm{E}+13$ & Akaike info criterion & 65.83063 \\
Sum squared resid & $6.86 \mathrm{E}+27$ & Schwarz criterion & 66.01219 \\
Log likelihood & -323.1532 & Hannan-Quinn criter. & 65.63147 \\
F-statistic & 0.016536 & Durbin-Watson stat & 2.010082 \\
Prob(F-statistic) & 0.999799 & & \\
\hline \hline
\end{tabular}




\section{Perhitungan Durbin Watson}

\begin{tabular}{|c|c|c|c|c|}
\hline \multirow{3}{*}{ Autokorelasi } & & \multicolumn{2}{|l|}{ Tidak } & \multirow{3}{*}{$\begin{array}{l}\text { Autokorela } \\
\text { si }\end{array}$} \\
\hline & Tanpa & terdapat & Tanpa & \\
\hline & Kesimpula & & & \\
\hline Negatif & $\mathrm{n}$ & Autokorelasi & Kesimpulan & Positif \\
\hline $\mathrm{dL}$ & $\mathrm{dU}$ & $\mathrm{dW}$ & $4-\mathrm{dU}$ & $4-d L$ \\
\hline 0,779 & 1.900 & 2.010 & 2,1 & 3,221 \\
\hline
\end{tabular}

Dari hasil analisis dengan menggunakan Eviews 10.0 dapat diketahui bahwa nilai Durbin Watson menunjukkan angka 2.010. Nilai dl dan du didapat dengan melihat tabel Durbin Watson dengan $\mathrm{n}=17 \mathrm{dan} \mathrm{k}=4$. Nilai $\mathrm{dl}$ sebesar 0,779 dan nilai du sebesar 1,900. Oleh karena nilai DW 2.010 lebih besar dari batas atas (du) 1.900. dan kurang dari 4-1.900 (dU $<$ DW $\leq 4-$ dU atau $1,900<2.010 \leq 2,1)$ maka dapat disimpulkan bahwa tidak ada autokorelasi positif maupun negatif atau dapat disimpulkan tidak terdapat autokorelasi. 


\section{c. Uji Heteroskedastisitas}

\section{Uji Heteroskedatisitas}

Heteroskedasticity Test: Glejser

\begin{tabular}{llll}
\hline \hline F-statistic & 0.544481 & Prob. F(3,6) & 0.6696 \\
Obs*R-squared & 2.139851 & Prob. Chi-Square(3) & 0.5439 \\
Scaled explained SS & 1.137015 & Prob. Chi-Square(3) & 0.7681 \\
\hline \hline
\end{tabular}

Test Equation:

Dependent Variable: ARESID

Method: Least Squares

Date: 04/14/20 Time: 00:03

Sample: 20082017

Included observations: 10

\begin{tabular}{crrrr}
\hline \hline \multicolumn{1}{c}{ Variable } & Coefficient & Std. Error & t-Statistic & Prob. \\
\hline \hline C & $-7.91 \mathrm{E}+13$ & $2.03 \mathrm{E}+14$ & -0.389277 & 0.7105 \\
X1 & -0.986662 & 1.037239 & -0.951238 & 0.3782 \\
X2 & 34197759 & 65253936 & 0.524072 & 0.6190 \\
X3 & -1.351677 & 6.194650 & -0.218201 & 0.8345 \\
\hline \hline R-squared & 0.213985 & Mean dependent var & $2.18 \mathrm{E}+13$ \\
Adjusted R-squared & -0.179022 & S.D. dependent var & $1.58 \mathrm{E}+13$ \\
S.E. of regression & $1.72 \mathrm{E}+13$ & Akaike info criterion & 64.07650 \\
Sum squared resid & $1.77 \mathrm{E}+27$ & Schwarz criterion & 64.19754 \\
Log likelihood & -316.3825 & Hannan-Quinn criter. & 63.94373 \\
F-statistic & 0.544481 & Durbin-Watson stat & 1.885375 \\
Prob(F-statistic) & 0.669640 & & \\
\hline \hline
\end{tabular}

Dari hasil analisis dengan menggunakan Eviews 10.0 di atas dapat diketahui bahwa Nilai X1,X2,X3 lebih besar dari alpha 0,05, sehingga Variabel $\mathrm{X} 1, \mathrm{X} 2, \mathrm{X} 3$ tidak berpengaruh dari Obs*R-square ini dapat disimpulkan $\mathrm{H} 1$ ditolak, dan $\mathrm{H} 0$ diterima atau tidak terjadi adanya masalah heteroskedastisitas pada data ini dan model regresi tersebut layak digunakan untuk memprediksi pertumbuhan ekonomi. 
Perbandingan Hasil Regresi dan Hipotesis awal

\begin{tabular}{|c|c|c|c|c|c|}
\hline \multirow[b]{2}{*}{ Variabel } & \multirow[b]{2}{*}{$\begin{array}{l}\text { Coofesie } \\
\text { n Regresi }\end{array}$} & \multicolumn{2}{|c|}{ Signifikansi } & \multicolumn{2}{|c|}{ Tanda Coofesien } \\
\hline & & $\begin{array}{c}\text { P- } \\
\text { Value }\end{array}$ & $\begin{array}{l}\text { Sig/Tid } \\
\text { ak }\end{array}$ & $\begin{array}{l}\text { Hipotes } \\
\text { is } \\
\text { Awal }\end{array}$ & $\begin{array}{c}\text { Hasil } \\
\text { Regresi }\end{array}$ \\
\hline Investasi & $2.604924^{-}$ & 0.2534 & tidak & positif & Negatif \\
\hline Tenaga Kerja & $\begin{array}{r}3.12 \mathrm{E}+0 \\
8\end{array}$ & 0.0051 & sig & positif & Positif \\
\hline $\begin{array}{l}\text { Pengeluaran } \\
\text { Pemerintah }\end{array}$ & 15.56077 & 0.0033 & $\operatorname{sig}$ & positif & Positif \\
\hline $\mathrm{C}$ & $\begin{array}{c}9.38 \mathrm{E}+1 \\
4\end{array}$ & 0.0004 & & & \\
\hline R-squared & 0.877255 & & & & \\
\hline $\begin{array}{c}\text { Adjusted R- } \\
\text { squared }\end{array}$ & 0.815883 & & & & \\
\hline $\begin{array}{c}\text { S.E. of } \\
\text { regression }\end{array}$ & $\begin{array}{r}3.42 \mathrm{E}+1 \\
3\end{array}$ & & & & \\
\hline $\begin{array}{c}\text { Sum squared } \\
\text { resid }\end{array}$ & $\begin{array}{r}7.00 \mathrm{E}+2 \\
7 \\
\end{array}$ & & & & \\
\hline $\begin{array}{c}\text { Log } \\
\text { likelihood }\end{array}$ & - & & & & \\
\hline F-statistic & 14.29396 & & & & \\
\hline $\begin{array}{l}\text { Prob(F- } \\
\text { statistic) }\end{array}$ & 0.000454 & & & & \\
\hline
\end{tabular}




\section{Uji Statistik}

\section{Persamaan Hasil Regresi}

Dependent Variable: PERTUMBUHAN

Method: Least Squares

Date: 04/13/20 Time: 23:48

Sample: 20082017

Included observations: 10

\begin{tabular}{lrrrr}
\hline \hline \multicolumn{1}{c}{ Variable } & Coefficient & Std. Error & t-Statistic & Prob. \\
\hline \hline C & $9.38 \mathrm{E}+14$ & $4.04 \mathrm{E}+14$ & 2.321197 & 0.0004 \\
X1 & -2.604924 & 2.062373 & 1.263072 & 0.2534 \\
X2 & $3.12 \mathrm{E}+08$ & $1.30 \mathrm{E}+08$ & 2.402224 & 0.0051 \\
X3 & 15.56077 & 12.31700 & 1.263357 & 0.0033 \\
\hline \hline & & & \\
R-squared & 0.877255 & Mean dependent var & $2.02 \mathrm{E}+14$ \\
Adjusted R-squared & 0.815883 & S.D. dependent var & $7.96 \mathrm{E}+13$ \\
S.E. of regression & $3.42 \mathrm{E}+13$ & Akaike info criterion & 65.45109 \\
Sum squared resid & $7.00 \mathrm{E}+27$ & Schwarz criterion & 65.57213 \\
Log likelihood & -323.2555 & Hannan-Quinn criter. & 65.31832 \\
F-statistic & 14.29396 & Durbin-Watson stat & 1.573580 \\
Prob(F-statistic) & 0.000454 & & \\
\hline \hline
\end{tabular}

\section{a. Hasil Uji Koefisien Determinasi (R-Squared)}

Koefisien determinasi $\left(\mathrm{R}^{2}\right)$ pada intinya mengukur seberapa jauh kemampuan model dalam menerangkan variasi variabel dependen (Y), sedangkan sisanya dijelaskan oleh variabel lain diluar model. Berdasarkan tabel 4.10 nilai R-Squared dalam penelitian ini sebesar 0.877255atau sebesar 87,72\% yang berarti variabel Investasi, Tenaga Kerjadan dan Pengeluaran Pemerintah menjelaskan variabel Pertumbuhan Ekonomi sebesar 87,72\% sedangkan sisanya $12,28 \%$ dijelaskan variabel lain yang tidak digunakan dalam penelitian ini. 


\section{b. Hasil Uji F-Statistik}

Untuk menguji hipotesis pengaruh simultan dari variabel independen (X) terhadap variabel dependen (Pertumbuhan Ekonomi), digunakan uji statistik F. Hasil dalam penelitian ini menujukan nilai Prob (F-Statistic) 0.0004 dimana nilai ini lebih kecil dari 0.05. Angka tersebut menunjukan bahwa hasil uji koefisien regresi simultan menerima $\mathrm{HO}$ sehingga bisa dibuat kesimpulan dalam penelitian ini yaitu, variabel Investasi, Tenaga Kerjadan dan Pengeluaran Pemerintah secara simultan berpengaruh signifikan terhadap variable Pertumbuhan Ekonomi.

\section{c. Hasil Uji t-Statistik}

Uji t-statistik digunakan untuk melihat apakah variabel Investasi, Tenaga Kerjadan dan Pengeluaran Pemerintah secara parsial berpengaruh signifikan.

Hasil Uji t-Statistik

\begin{tabular}{|c|c|c|}
\hline Variabel & Nilai Probabilitas & $\begin{array}{c}\text { Hipotesis yang } \\
\text { diterima }\end{array}$ \\
\hline Investasi & 0.2534 & $\begin{array}{c}\text { H0 yang berarti } \\
\text { Investasi tidak } \\
\text { berpengaruh } \\
\text { terhadap Pertumbuhan } \\
\text { Ekonomi }\end{array}$ \\
\hline Tenaga Kerja & \multirow{2}{*}{0.0051} & $\begin{array}{c}\text { H1 yang berarti } \\
\text { tenaga kerja } \\
\text { berpengaruh }\end{array}$ \\
& & $\begin{array}{c}\text { terhadap Pertumbuhan } \\
\text { Ekonomi. }\end{array}$ \\
\hline Pengeluaran & \multirow{2}{*}{$\begin{array}{c}\text { H1 yang berarti } \\
\text { Pengeluaran } \\
\text { Pemerintah }\end{array}$} & $\begin{array}{c}\text { pemerintah } \\
\text { berpengaruh terhadap } \\
\text { Pertumbuhan Ekonomi }\end{array}$ \\
\hline
\end{tabular}

\section{d. Uji Signifikansi Parameter Individual (Uji Statistik t)}

Berdasarkan hasil estimasi dengan Model Regresi $\boldsymbol{U} \boldsymbol{j i} \boldsymbol{T}$ Statistik dan 
telah diolah dalam tabel 4.10 maka dapat dibuat model persamaan untuk penelitian ini yaitu : $P E=9.38 E+14-2.604924$ Investasi +3.127108

\section{Tenaga Kerja + 15.56077 Pengeluaran Pemerintah $+e$}

- Variabel Investasi (Nilai koefisien regresi variabel Investasi memiliki hubungan yang bernilai Negatif sebesar -2.604924 menjelaskan bahwa apabila terjadi peningkatan pada Investasi sebesar $1 \%$ maka nilai pertumbuhan ekonomi akan mengalami penurunan sebesar $\mathbf{- 2 . 6 0 4 9 2 4}$ dengan faktor lain dianggap tetap. Sebaliknya jika ada penurunan pada Investasi sebesar 1\% maka nilai pertumbuhan ekonomi akan meningkat sebesar -2.604924 dengan faktor lain dianggap tetap)

- Variabel Tenaga Kerja (Nilai koefisien regresi variabel Tenaga Kerja memiliki hubungan positif sebesar 3.127108 menjelaskan bahwa apabila terjadi peningkatan pada tenaga kerja sebesar 1\% maka nilai pertumbuhan ekonomi akan mengalami peningkatan sebesar 3.127108 dengan faktor lain dianggap tetap. Sebaliknya jika ada penurunan pada tenaga kerja sebesar 1\% maka nilai pertumbuhan ekonomi akan turun sebesar 3.127108 dengan faktor lain dianggap tetap)

- Variabel Pengeluaran Pemerintah (Nilai koefisien regresi variabel Pengeluaran Pemerintah memiliki hubungan positif sebesar 15.56077 menjelaskan bahwa apabila terjadi peningkatan pada Pengeluaran Pemerintah sebesar 1\% maka nilai pertumbuhan ekonomi akan mengalami peningkatan sebesar $\mathbf{1 5 . 5 6 0 7 7}$ dengan faktor lain dianggap tetap. Sebaliknya jika ada penurunan pada tenaga kerja sebesar 1\% maka nilai pertumbuhan ekonomi akan turun sebesar 15.56077 dengan faktor lain dianggap tetap.

\section{PEMBAHASAN HASIL ESTIMASI}

1. Pengaruh Investasi terhadap Pertumbuhan Ekonomi

\section{Sumatera Selatan}

Variabel Investasi menunjukan pengaruh yang tidak signifikan terhadap 
Pertumbuhan ekonomi, hal tersebut dinyatakan pada uji t bahwa, variabel Investasi pada tingkat kepercayaan 5\% memiliki probabilitas $0.2534>0.05$, yang artinya penambahan investasi suatu daerah tidak terlalu berpengaruhi untuk pertumbuhan pertumbuhan ekonomi. Hasil penelitian ini sesuai dengan penelitian terdahulu yang dilakukan oleh Didi Nuryadin (2015). Menyatakan bahwa tidak terdapat pengaruh positif dan signifikan terhadap pertumbuhan ekonomi. Dari hasil tersebut tidak sejalan dengan teori yang sudah ada, semakin tinggi nilai investasi maka pertumbuhan akan mengalami peningkatan.

Fluktuasi Investasi Sumatera Selatan Tahun 2008-2017 (\%)

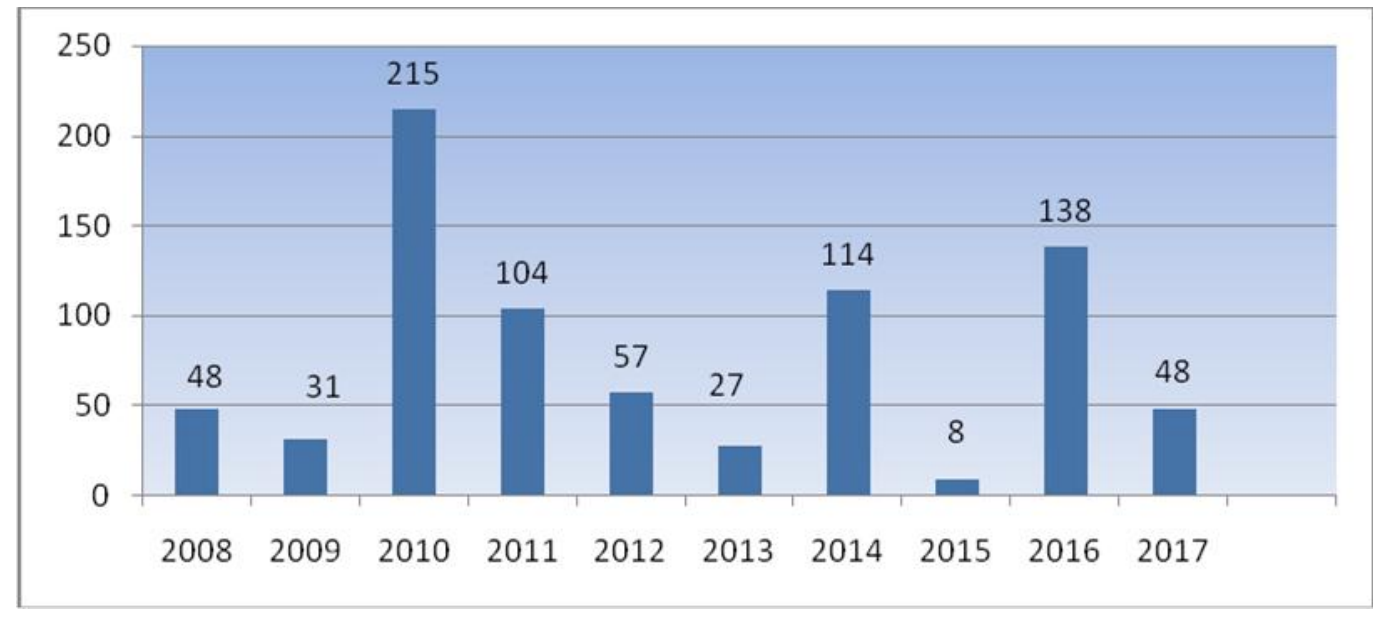

Sumber : BPS Prov. Sumatera Selatan (data diolah)

Ketidaksignifikannya investasi dengan pertumbuhan ekonomi di Sumatera Selatan dapat dilihat pada tahun 2014. Hal ini disebabkan karena Investasi bukan merupakan satu-satunya faktor yang berperan besar dalam peningkatan pertumbuhan ekonomi di Sumatera Selatan. Realisasi investasi tahun 2014 meningkat 114,1\% atau sebesar Rp 21,8 triliun, namun pertumbuhan ekonomi hanya sebesar 4,68\% (Gambar 4.2). Hal ini menunjukkan bahwa pertumbuhan investasi yang tinggi tidak mempengaruhi pertumbuhan ekonomi.

Dari analisis ini menjelaskan bahwa para investor lebih banyak dan 
dominan menanamkan modalnya dalam sektor sekunder yaitu industri makanan, dan transportasi wilayah perkotaan saja bukan pada sektor primer yang ada di daerah, yaitu tanaman pangan dan perkebunan, pertanian, transportasi, gudang dan telekomunikasi, industri di daerah-daerah lainnya yang mendorong tumbuhnya perekonomian di Sumatera Selatan.

\section{Pengaruh Tenaga Kerja terhadap Pertumbuhan Ekonomi}

Variabel tenaga kerja menunjukan pengaruh yang signifikan terhadap Pertumbuhan ekonomi, hal tersebut dinyatakan pada uji t bahwa, variabel tenaga kerja pada tingkat kepercayaan 5\% memiliki probabilitas $0.0051<0.05$, hasil ini sesuai dengan hasil penelitian Sodik (2015) yang menunjukkan bahwa tenaga kerja dilihat dari proxy angkatan kerja memiliki pengaruh yang signifikan terhadap pertumbuhan ekonomi di Indonesia. Dari sudut pandang proses produksi maka keberadaan tenaga kerja merupakan salah satu input atau faktor produksi.

Untuk memaksimalkan hasil produksi adalah dengan meningkatkan kualitas tenaga kerja. Kualitas tenaga kerja yang baik tentunya akan memberikan hasil pekerjaan yang baik pula. Tingkat angkatan kerja Sumatera Selatan dari tahun 2008 hingga 2017 mengalami kenaikan walaupun tidak terlalu besar. Pada tahun 2010 kenaikan sebesar 7,01\%, walaupun sempat mengalami penurunan pada tahun berikutnya yang di akibatkan melambatnya pergerakan ekonomi dan meningkatnya jumlah tingkat pengangguran terbuka (TPT), namun pada tahun 2016 meningkat sebesar 8.19\% dari sedikit menurun pada tahun 2017 sebesar -1,4\%. 
Fluktuasi Tenaga Keja Sumatera Selatan Tahun 2008-2017 (\%)

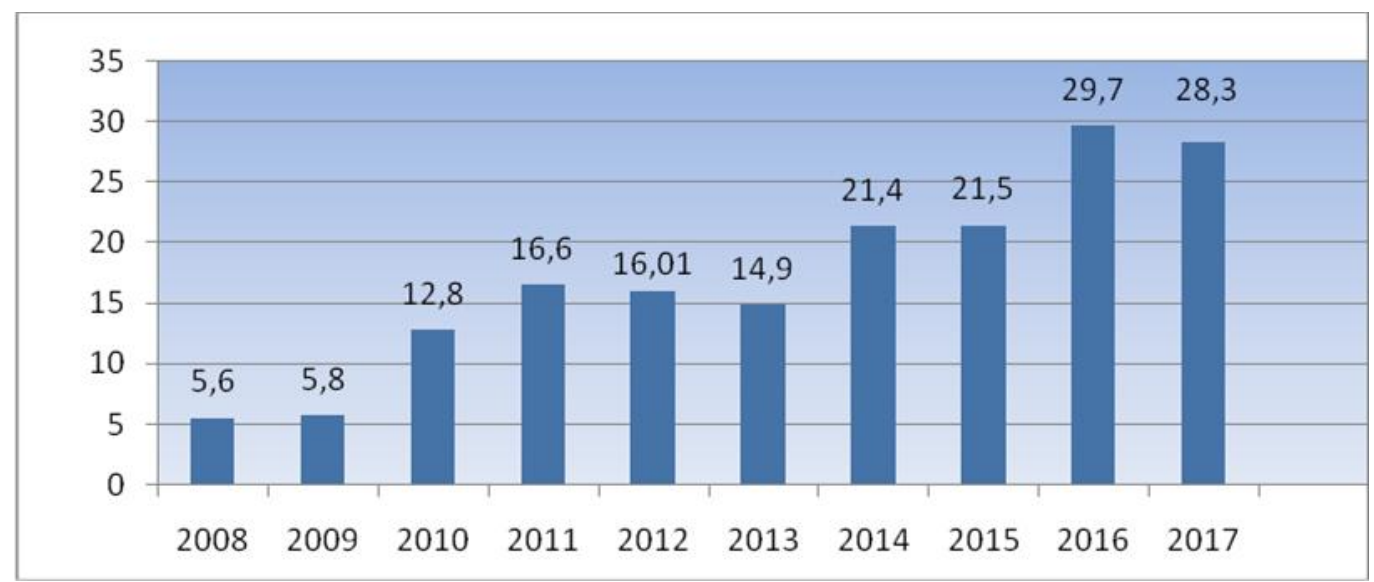

Sumber : BPS Prov. Sumatera Selatan (data diolah)

Sektor pertanian tetap berada di posisi teratas dalam hal penyerapan tenaga kerja. Kontribusi sektor pertanian terhadap produk domestik bruto (PDB) Sumatera Selatan tahun 2016 mencapai 1,9 juta orang atau sekitar 8,2\% dari tahun sebelumnya. tertinggi kedua adalah sektor jasa kemasyarkatan, sosial dan perorangan yang berkontribusi terhadap PDB Indonesia sebesar 1564,8\%. Setengah dari separuh PDB adalah berbasis pertanian. Meningkatnya kontribusi sektor pertanian terhadap pertumbuhan ekonomi tidak terlepas dari upaya pemerintah untuk terus mendorong peningkatan produksi pangan, terutama komoditas-komoditas strategis

Hal ini didukung dengan jumlah penduduk Indonesia yang banyak pada usia produktif sehingga kebijakan pemerintah meningkatkan jumlah tenaga kerja melalui program padat karya seperti PNPM akan berdampak positif. Hasil tersebut juga sesuai dengan teori pertumbuhan output total dan teori pertumbuhan Solow yang menyatakan peningkatan jumlah tenaga kerja yang pesat dapat mempercepat pula laju pertumbuhan ekonomi. Karena tenaga kerja merupakan pelaku dan pengelola faktor produksi lainnya sehingga peningkatan jumlah tenaga kerja di Indonesia akan berdampak positif terhadap peningkatan pertumbuhan ekonomi. 


\section{Pengaruh Belanja Pemerintah terhadap Pertumbuhan Ekonomi}

Variabel belanja pemerintah menunjukan pengaruh yang signifikan terhadap Pertumbuhan ekonomi, hal tersebut dinyatakan pada uji t bahwa, variabel belanja pemerintah pada tingkat kepercayaan 5\% memiliki probabilitas $0.0033<0.05$, hasil ini sesuai dengan penelitian yang dilakukan oleh Taufan dan Heny (2014). Hasil penelitian mereka menunjukan bahwa belanja modal berpengaruh negatif terhadap PDRB.

Dilihat dari perkembangan beberapa tahun terakhir, anggaran belanja pemerintah mengalami peningkatan. Hal ini terjadi karena adanya langkahlangkah kebijakan yang diambil oleh pemerintah dalam mengantisipasi berbagai perkembangan di bidang ekonomi dan non ekonomi, di samping untuk menimbangi dari semakin meningkatnya penerimaan negara secara nominal.

\section{Pengeluaran Pemerintah Sumatera Selatan Tahun 2008-2017}

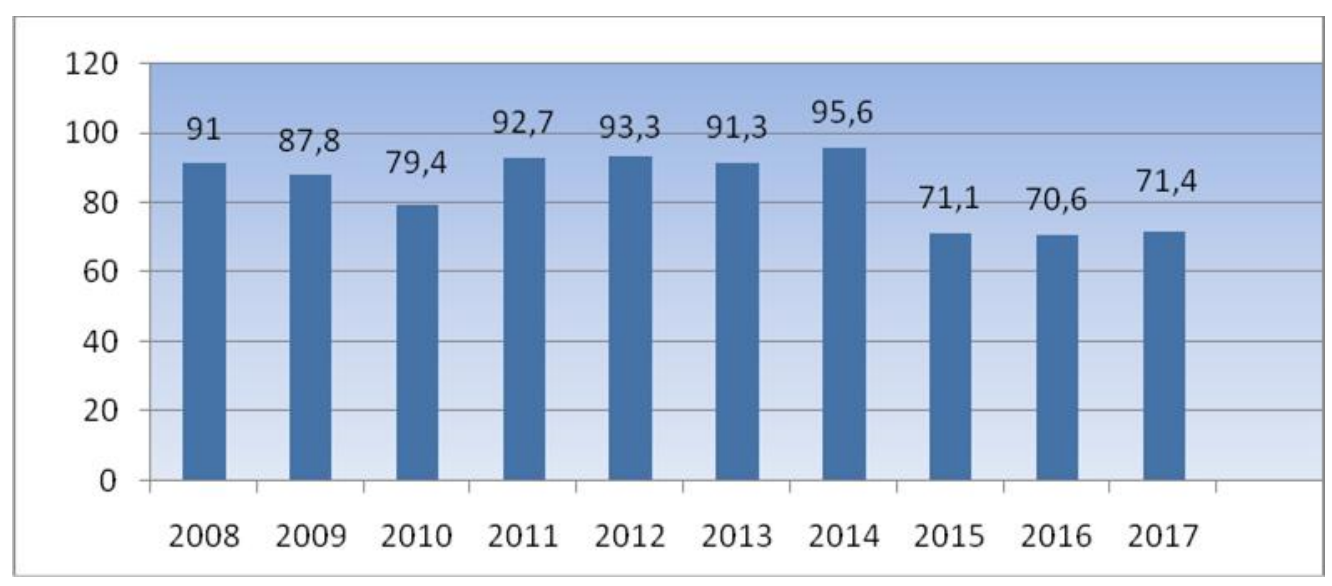

Sumber : BPS Prov. Sumatera Selatan (data diolah)

Nilai koefisien regresi variabel Belanja Pemerintah yang bernilai Positi sebesar 15.56077 menjelaskan bahwa apabila terjadi peningkatan pada Belanja Pemerintah sebesar 1\% maka nilai pertumbuhan ekonomi akan mengalami peningkatan sebesar 15.56077 dengan faktor lain dianggap tetap..

Realisasi belanja modal pemerintah Provinsi sumsel tahun 2017 
mencapaii Rp 6,4 Triliun, atau secara pertumbuhan belanja modal sebesar 0,8\% dari tahun sebelumnya. melambat cukup signifikan dibandingkan dengan tahun 2011 yang tumbuh 95,6\% .

Pada tahun 2014, realisasi belanja Provinsi Sumatera Selatan sebesar 95,6\% dari total anggaran belanja. Angka ini lebih tinggi dibandingkan dengan persentase realisasi periode yang sama tahun sebelumnya atau sesudahnya. Meningkatnya realisasi ini terutama didorong oleh peningkatan belanja tidak langsung yang memiliki peran dominan, yakni sebesar 4,10 Triliun atau 69,4\%. Berdasarkan jenisnya, realisasi belanja pada tahun 2014 terutama didorong oleh peran komponen belanja Hibah, yakni sebesar 1,5 Triliun atau 27,23\% dari total belanja. Sementara belanja modal hanya sebesar 12,68\%.

Secara total belanja pemerintah Provinsi Sumatera Selatan selama tahun 2014 sebesar Rp 5,78 triliun atau meningkat 4,3\% dibandingkan tahun sebelumnya, yang sebagian besar dialokasikan untuk pengembangan sektor infrastruktur, fasilitas di PTN dan alokasi untuk dana desa. Di sisi lain, realisasi belanja pemerintah masih relatif rendah, baru mencapai angka 23,9\%. Rendahnya realisasi ini terjadi seiring dengan adanya beberapa kendala yang muncul, seperti permasalahan numenklatur yang masih terjadi di beberapa Kementerian, masih belum selesainya proses lelang di berbagai proyek, kontraktor yang tidak mencairkan anggaran sesuai dengan termin proyek, penolakan pegawai untuk menjadi Pejabat Pembuat Komitmen (PPK) dan permasalahan administrasi proyek yang cukup panjang.

\section{KESIMPULAN}

Berdasarkan Hasil dan Pembahasan sebelumnya maka dapat dibuat beberapa kesimpulan yaitu sebagai berikut :

Investasi di Sumatera Selatan memiliki hasil yang tidak berpengaruh terhadap pertumbuhan ekonomi. Hal ini disebabkan karena Investasi bukan 
merupakan satu-satunya faktor yang berperan besar dalam peningkatan pertumbuhan ekonomi di Sumatera Selatan. Selain itu investasi lebih condong ke arah perkotaan saja, sedangkan demografi lebih banyak area daerah yang sumber penghasilannya adalah pertanian, Penggunaan Investasi untuk pembangunan sering kurang tepat sasaran, sehingga tidak dapat meningkatkan pertumbuhan ekonomi.

Jumlah tenaga kerja di Sumatera Selatan memiliki hasil yang berpengaruh dan juga memiliki hubungan yang positif dengan pertumbuhan ekonomi Sumatera Selatan. Jumlah tenaga kerja dari tahun ke tahun mengalami peningkatan, dengan bertambahnya jumlah penduduk yang bekerja di Sumatera Selatan maka diharapkan produktivitas dari tenaga kerja akan semakin meningkat sehingga hal ini dapat memacu pertumbuhan ekonomi di Sumatera Selatan.

Belanja pemerintah memiliki hasil yang berpengaruh terhadap pertumbuhan ekonomi di Sumatera Selatan mengimplikasikan bahwa pertumbuhan pengeluaran pemerintah sangat dibutuhkan dalam meningkatkan perekonomian, dalam hal ini adalah kebijakan pemerintah dalam mengatur dan mengendalikan pengeluarannya baik pengeluaran rutin maupun pengeluaran pembangunan. Belanja modal adalah salah satu factor terbesar penyumbang meningkatnya pertumbuhan ekonomi di Sumatera Selatan. Permodalan yang meliputi tanah, mesin, bangunan, transportasi dan media komunikasi. Karakteristik modal meningkatkan ketersediaan modal per satu tenaga kerja yang semakin meningkatkan rasio modal atau rasio tenaga kerja. Sebagai dampaknya, produktivitas tenaga kerja meningkat yang berujung pada peningkatan produksi dan pertumbuhan ekonomi. 


\section{DAFTAR PUSTAKA}

Ali, Nuruddin Muhammad. 2006. Zakat Sebagai Instrumen dalam Kebijakan Fiskal. Jakarta: PT. Raja Grafindo Persada.

Antonio, Muhammad Syafi'i. SAW: The Super. Leader 2007 Super. Manager. Jakarta: ProLM Centre \& Tazkia Multimedia.

Badan Pusat Statistik, Provinsi Sumatera Selatan Dalam angka Tahun, berbagai tahun penerbitan), BPS Provinsi Sumatera Selatan,2015.

Boediono, Teori Pertumbuhan Ekonomi, Seri Sinopsis Pengantar Ilmu ekonomi, Edisi 1, Cetakan Ke 5, BPFE, Jogyakarta, 1992.

Cortes, Mariluz, Albert Berry dan Asfaq Ishaq. 1987. Succses in Small and Medium Scale Entreprise (diterbitkan untuk bank dunia oleh Oxford university Press)

Dumairy, Perekonomian Indonesia, Cetakan Kedua, Penerbit Erlangga Jakarta,1997.

Gudgin, Grahan. 1979. Industrial Location Process and Employment Growth (London : Gower, 1997), 8 dan lihat pula David Birch, The Job Generation, Process (Cambridge, Mass : MIT Program on Neigbourhood and Regional Change).

Gujarati, Damodar,Ekonometrika Dasar : Edisi Keenam. Erlangga, Jakarta, 2003.

Guritno, Ekonomi publik, BPFE, Yogyakarta.2002.

Idrus, Muhammad, metode penelitian Ilmu-Ilmu Sosial (Pendekatan Kuantitatif dan kualitatif) (Yogyakarta :UII Press), 2007.

Jones, Charles O,.Pengantar Kebijakan Publik Terjemahan, Edisi 1. Jakarta: PT. Raja Grafindo Persada,1996 
Lidholm, Carl dan Donald Mead. 1998. Small Scale Enterprise : A Profile, diproduksi kembali dari Small Scale Industries in Developing Countries : Empirical Epidence and Policy Implication, Michigan State University Development Paper (Economic Impact 2)

Litte, Ian, Tibor Scietovsky dan Maurice Scott. 1970. Industri and Trade in Some Developing Countries (London, Oxford University Press)

Lincoln. Arsyad, Ekonomi Pembangunan, Edisi 4 Cetakan Pertama, Yogyakarta, Penerbit Bagian Penerbitan Sekilah Tinggi Ilmu Ekonomi YKPN,1999.

Mankiw, N. Gregory, Teori Makro Ekonomi Terjemahan, PT Gramedia Pustaka Utama, Jakarta,2001.

Mangkoesoebroto, Guritno, Kebijakan Ekonomi Publik di Indonesia : Substansi dan Urgensi, Cetakan Pertama, Jakarta : PT. Gramedia Pustaka Umum, 1998.

Musgrave, Richard A. dan Peggy Musgrave, Kenangan Negara dalam Teori dan Praktek (edisi Bahasa Indonesia), Penerbit Erlangga, Jakarta, 1993.

Rosyidi, Suherman.2014. Pengantar Teori Ekonomi: Pendekatan kepada Teori Ekonomi Mikero dan Makro. Jakarta: Rajawali Pers.

Simanjuntak, Payaman J.,Pengantar Ekonomi Sumber Daya Manusia. Jakarta: Lembaga Penerbit Fakultas Ekonomi Universitas Indonesia,1995.

Sumitro, Djojohadikusumo, Perkembangan Pemikiran Ekonomi, Pertumbuhan dan Ekonomi Pembangunan, Jakarta: Pustaka LP3ES Indonesia, 1993.

Sukirno, Sadono, Makroekonomi Teori Pengantar Edisi Ketiga. Jakarta: Rajawali Pers, 2012.

Todaro, Michael P., dan Smith, Stephen C., Pembangunan Ekonomil 
EdisiKesembilan, Jilid 1 (Alih Bahasa: Haris Munandar dan Puji A.L.). Jakarta:Penerbit Erlangga,2006.

Yuwono, Prapto,Pengantar Ekonometri. Yogyakarta: ANDI,2005.

Yunus, Muhammad.1988.The Poor as the Engine of Development (Economic Impact 2) 